\title{
Effect of Polymer Topology on non-covalent Polymer-Protein Complexation: Miktoarm versus Linear mPEG-poly(glutamic acid) Copolymers
}

\author{
Alejandro Nieto-Orellana, ${ }^{a}$ Marco Di Antonio, ${ }^{\mathrm{b}}$ Claudia Conte, ${ }^{a}$ Franco H. Falcone, ${ }^{\mathrm{a}}$ Cynthia Bosquillon, ${ }^{a}$ Nick \\ Childerhouse, ${ }^{c}$ Giuseppe Mantovani*a and Snow Stolnik*a
}

Non-covalent polymer-protein conjugation is emerging as a potential route to improve pharmacokinetics and pharmacodynamics of protein therapeutics. In this study, a family of structurally related block copolymers of $\mathrm{mPEG}_{2 \mathrm{k}}$ - poly(glutamic acid) with linear A-B (mPEG $2 \mathrm{k}$-lin-polyGA) and miktoarm A-B $\left(\left(\mathrm{mPEG}_{2 \mathrm{k}}-\mathrm{mik}_{\mathrm{k}} \text {-(polyGA) }\right)_{3}\right)$ structure was synthesised by $\mathrm{N}$-carboxyanhydride (NCA) ring-opening polymerisation to assess the effect of macromolecular topology of the copolymers on polymer-protein complexation. The data illustrate that the synthesised copolymers are capable of complexing a model protein, lysozyme, at optimal pH conditions through non-covalent interactions, with complexation efficiencies depending on the copolymers composition and molecular architecture. In native gel electrophoresis experiments, linear $\mathrm{mPEG}_{2 \mathrm{k}}$-lin-GA $\mathrm{A}_{10}$ copolymer, possessing a short polyanionic polyGA block, shows a low level of complexation, which does not change when the number of polyGA branches of the same size is increased, using a miktoarm mPEG $2 k-m i k-\left(G_{10}\right)_{3}$ copolymer. However, enhanced complexation is observed when the same number of ionisable GA units (30) are displayed on a linear macromolecular scaffold; $\mathrm{mPEG}_{2 \mathrm{k}}$-mik- $\left(\mathrm{GA}_{10}\right)_{3}$ vs. $\mathrm{mPEG}_{2 \mathrm{k}}$-lin- $\mathrm{GA}_{30}$. Again complexation efficiency did not increase when the number of complexing polyGA branches were increased; mPEG $2 k-$ lin-GA 30 vs. mPEG $2 k-m i k-(G A 30)_{3}$. Nanoparticle tracking analysis (NTA) showed that the copolymer-protein complexes possessed hydrodynamic diameters in the 50-200 $\mathrm{nm}$ range, suggesting a degree of control in the assembly process. Sequestration of lysozyme within polymer complexes resulted in a decrease in its apparent enzymatic activity, which was reestablished on the complexes dissociation upon a treatment with competitive complexant. Intrinsic fluorescence and circular dichroism (CD) studies suggested structural conformation of the protein was not altered following

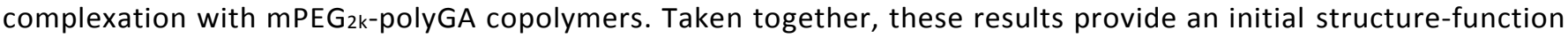
relationship for protein-complexing $\mathrm{mPEG}_{2 \mathrm{k}}$-polyGA copolymers with variable macromolecular topology, opening the way for their future application in biological and biomedical studies.

\section{Introduction}

The global market of biotech drug sales has experienced an important growth over the past few decades and is expected to reach 445 billion of dollars by $2019 .{ }^{1}$ In particular recent advances in biotechnology, genetic engineering and molecular biology have resulted in a range of potential protein therapeutics which could address different unmet medical needs. However, effective protein delivery to the desired bodily target can be very challenging, due to potential immunogenicity, ${ }^{2}$ poor stability ${ }^{3}$ and often inefficient permeation of proteins through biological membranes. Nanomedicines, especially polymer-based nanosystems, are emerging as a potential strategy to overcome these therapeutic challenges. Bioconjugates, where a synthetic polymer, typically polyethyleneglycol (PEG), is covalently linked to a protein or peptide therapeutic, are one successful example of such an approach. PEGylation can increase the protein/peptide half-life by reducing its immunogenicity and plasma stability, and by decreasing the rate of its renal glomerular filtration. ${ }^{4,5}$ This has resulted in a number of PEGylated protein and peptide therapeutics being available on the market. ${ }^{6}$ However, covalent polymer conjugation is not suitable for all proteins as it can potentially decrease their therapeutic efficacy due to irreversible modification or steric shielding of protein active site $^{7}$ and does not answer all the challenges in protein-peptide delivery. Within this context, non-covalent protein-polymer formulations are emerging as potentially suitable alternatives. Recent examples include the work by the Salmaso and Caliceti's group, where a family of PEGs bearing a terminal cholanic moiety ( $\mathrm{mPEG}_{5 \mathrm{kDa}}$-cholane) 
were utilised to generate polymer conjugates through non-covalent hydrophobic interactions with a range of protein and peptides, including recombinant human granulocyte colony stimulating factor (rh-G-CSF), ${ }^{8}$ palmytoilated vasoactive intestinal peptide (VIP), ${ }^{9}$ and recombinant human growth hormone (rh-GH). ${ }^{10}$ Crowley and co-workers have recently exploited specific carbohydrate-lectin recognition to design a $\alpha$-L-fucose-terminated PEG able to reversibly PEGylate RSL trimer lectin. ${ }^{11}$ The intrinsically reversible nature of these interactions can allow complex disassembly under specific conditions - e.g. those found in the proximity of the intended biological target - which can offer therapeutic advantages. Additionally, these complexes can be assembled by simply mixing protein and polymer components under appropriate conditions, avoiding the often complex conjugation chemistries required for covalent PEGylation.

Complexes assembled through ionic protein-polymer interactions are a particularly attractive class of protein conjugates. Stable complexes in nanometre size range have been assembled from PEG-polyanion/polycation copolymers and charged macromolecules including proteins ${ }^{12}$ and DNA. ${ }^{13}$ Nanocomplexes with average diameter of around $50 \mathrm{~nm}$ were produced from lysozyme and PEG-b-poly(aspartic acid) ${ }^{12}$ or insulin and oligolysine or oligoarginine-type homopeptide functionalised with PEG.$^{14}$ These nanocomplexes are typically assembled using linear (co)polymers, ${ }^{14-16}$ whilst the use of macromolecules with more complex topologies such as dendrimer, ${ }^{17}$ graft $^{18}$ or miktoarm ${ }^{19}$ structures, all of which could provide unique protein binding modalities, has been largely unexplored.

In the present study we developed a family of PPEG $_{2 k}$-poly(glutamic acid) copolymers with either linear A-B, or miktoarm $A-B_{3}$ structure, where the polyanion poly(glutamic acid) arm(s) are designed to provide ionic complexation with model protein lysozyme, whilst the $\mathrm{PEG}_{2 \mathrm{k}}$ block infer steric stabilisation and minimises, or ideally, prevents secondary aggregation of the complexes. ${ }^{12}$ Poly(glutamic acid) is a widely investigated polymer ${ }^{20,21}$, and was chosen in this study because of its low toxicity - e.g. it has been used as a macromolecular carrier in poly(GA)-paclitaxel conjugates that are being investigated in clinical trials for the treatment of a range of malignancies, including esophageal, ${ }^{22,}{ }^{23}$ ovarian, ${ }^{24,}{ }^{25}$ non-small-cell lung cancer, ${ }^{26-29}$ and glioblastoma multiforme - and the presence of multiple ionisable carboxylic acid group groups along its polymer chain which potentially could allow complexation of proteins presenting positively charged surface residues.

Miktoarm star polymers - often simply referred to as miktoarm polymers - are star-shaped polymers where two or more macromolecular arms differ for their chemical composition, size, or both. ${ }^{19,30,31}$ The growing interest in miktoarm polymers comes from the possibility to incorporate both a variable number of polymer arms, and a plethora of chemical functionalities within one single macromolecule. ${ }^{31}$ Studies have specifically focussed on the differences in self-assembly modalities of amphiphilic miktoarm copolymers compared to their linear analogues. ${ }^{32,33}$

The use of miktoarm polymers to engineer drug deliver vectors and formulations is still in its infancy, with known examples being limited to micellar and polymersomal nanovectors. ${ }^{34-37}$ Bae and co-workers synthesised a library of Y-shaped $A B_{2}$ copolymers incorporating one PEG chain and two PLGA arms, which could be assembled into 33-75 nm polymersomes, and which could encapsulate doxorubicin hydrochloride and released it in a controlled fashion. ${ }^{37}$ Importantly, due to their macromolecular structure these miktoarm copolymers could form polymersomes in a much broader range of PEG volume fractions $(0.2-0.7)$ than their linear diblock counterparts $(0.2-0.4)$.

In this work, $\mathrm{A}-\mathrm{B}_{3}$ (mPEG-mik-(polyGA) $)_{3}$ ) miktoarm polymers were investigated along with their linear A-B mPEG-lin(polyGA) analogues for their ability to form nanocomplexes with egg white lysozyme model protein, with the aim of identifying a structure-function relationship for this novel linear and miktoarm family of complexing copolymers.

\section{Experimental}

3,4,5-tris(allyloxy)benzoic acid methyl ester (1). Methyl 3,4,5-trihydroxybenzoate (4.5 g, $25 \mathrm{mmol}, 1.0$ eq.) and $\mathrm{K}_{2} \mathrm{CO}_{3}$ $(16.4 \mathrm{~g}, 119 \mathrm{mmol}, 4.8 \mathrm{eq}$.), were added to a round bottomed flask. Anhydrous acetonitrile $(125 \mathrm{~mL})$ and allyl bromide $\left(21.0 \mathrm{~g}, 174 \mathrm{mmol}, 7.0\right.$ eq.) were then added to the mixture under $\mathrm{N}_{2}$ atmosphere via syringe. The mixture was then heated to reflux and stirred whilst protected from the light. After 3 hours ${ }^{1} \mathrm{H}$ Nuclear Magnetic Resonance (NMR) showed completed conversion of the aromatic alcohol functionalities into their corresponding allyl ethers. Volatiles were then removed under reduced pressure. Toluene $(200 \mathrm{~mL})$ was added to the resulting residue, and the insoluble salts were filtered off and washed with additional portions of toluene $(3 \times 100 \mathrm{~mL})$. The toluene fractions were combined, and the solvent removed under pressure to give the desired product (1) as an oil which was used for the next step without further purification. Yield $7.5 \mathrm{~g}$, quant. ${ }^{1} \mathrm{H}$ NMR $\left(400 \mathrm{MHz}, \mathrm{CDCl}_{3}, \delta, \mathrm{ppm}\right): 7.28$ (s, $2 \mathrm{H}, \mathrm{CH}_{\text {aromatic }}$ ), 6.14-6.01 (m, 3Hallyl $), 5.47-5.16\left(\mathrm{~m}, 6 \mathrm{H}_{\text {allyl }}\right), 4.65-4.59\left(\mathrm{~m}, 6 \mathrm{H}, \mathrm{OCH}_{2}\right), 3.88\left(\mathrm{~s}, 3 \mathrm{H}, \mathrm{CH}_{3} \mathrm{O}\right) .{ }^{13} \mathrm{C} \mathrm{NMR}\left(101 \mathrm{MHz}, \mathrm{CDCl}_{3}, \delta\right.$, ppm): 166.7, 152.4, 142.0, 134.3, 133.1, 125.1, 118.0, 117.8, 108.9, 74.2, 70.0, 52.3. ESI-TOF mass spectrometry: expected $\mathrm{m} / \mathrm{z}\left[\mathrm{M}-\mathrm{H}^{+}\right]$theor. 305.13, found 305.12. FT-IR: $1715 \mathrm{~cm}^{-1}$ (回c=0). 
3,4,5-tris(allyloxy)benzoic acid (2). To a solution of ester (1) $(7.5 \mathrm{~g}, 25 \mathrm{mmol})$ in $\mathrm{CH}_{2} \mathrm{Cl}_{2} / \mathrm{MeOH}(9: 1 \mathrm{v} / \mathrm{v}, 20 \mathrm{~mL}), 160 \mathrm{~mL}$ of a $3.33 \mathrm{M}$ solution of $\mathrm{NaOH}$ in methanol was added into a round bottomed flask obtaining a final alkali concentration of $2.82 \mathrm{M}$. The mixture was stirred at room temperature, and after 14 hours TLC (petroleum ether/ethyl acetate 6:4) revealed the absence of starting material (1). The solvents were then removed under reduced pressure; the resulting residue was mixed with distilled water $(200 \mathrm{~mL})$ and extracted with diethyl ether $(3 \times 100 \mathrm{~mL})$ in order to remove any traces of unreacted ester starting material (1). The aqueous phase was then acidified with $\mathrm{HCl} 2 \mathrm{M}$ to $\mathrm{pH} 2$ and extracted with dichloromethane $(3 \times 100 \mathrm{~mL})$. The combined organic layers were dried over $\mathrm{MgSO}_{4}$, filtered, and the solvent removed under reduced pressure to give (2) as an oil (yield $6.0 \mathrm{~g}, 84 \%) .{ }^{1} \mathrm{H}$ NMR $(400 \mathrm{MHz}, \mathrm{CDCl}, \delta, \mathrm{ppm})$ : 7.35 (s, 2H, CHaromatic), 6-14-6.03 (m, 3Hally) $)$ 5.47-5.16 (m, 6 $\left.\mathrm{H}_{\text {allyl }}\right), 4.66-4.62\left(\mathrm{~m}, 6 \mathrm{H}, \mathrm{OCH}_{2}\right){ }^{13} \mathrm{C} \mathrm{NMR}\left(101 \mathrm{MHz}, \mathrm{CDCl}_{3}\right.$, $\delta, \mathrm{ppm}): 171.4,152.4,142.0,134.3,133.1,123.9 .1,118.0,117.8,108.9,74.2,70.0$. ESI-TOF mass spectrometry: expected $\mathrm{m} / \mathrm{z}\left[\mathrm{M}-\mathrm{H}^{+}\right]$291.32, found 291.41. FT-IR: $1687 \mathrm{~cm}^{-1}$ (回c=0).

3,4,5-tris(allyloxy)benzoyl chloride (3). Compound (2) $(1.0 \mathrm{~g}, 3.4 \mathrm{mmol}, 1.0$ eq.) was dissolved in anhydrous dichloromethane $(50 \mathrm{~mL})$. Anhydrous DMF catalyst (2 drops) and oxalyl chloride $(0.66 \mathrm{~g}, 5.2 \mathrm{mmol}, 1.5$ eq.) were added to the solution under $\mathrm{N}_{2}$ atmosphere via syringe. The mixture was stirred at room temperature for $1 \mathrm{~h}$, until evolution of gas could no longer be observed. The volatiles were then removed under reduced pressure, and the residue was redissolved in dichloromethane and the solvent removed under reduced pressure. This procedure was repeated several times in order to remove all traces of residual oxalyl chloride and provide analytically pure (3) as orange viscous oil, which was used for next step without further purification. Yield: $1.0 \mathrm{~g}$, quant. ${ }^{1} \mathrm{H} \mathrm{NMR}(400 \mathrm{MHz}$, $\left.\mathrm{CDCl}_{3}, \delta, \mathrm{ppm}\right): 7.35\left(\mathrm{~s}, 2 \mathrm{H}, \mathrm{CH}_{\text {aromatic }}\right), 6.08-5.97\left(\mathrm{~m}, 3 \mathrm{H}_{\text {allyl }}\right), 5.44-5.15\left(\mathrm{~m}, 6 \mathrm{H}_{\text {allyl }}\right), 4.66-4.58(\mathrm{~m}, 6 \mathrm{H}, \mathrm{OCH}) .{ }^{13} \mathrm{C} \mathrm{NMR}$ $\left(101 \mathrm{MHz} \mathrm{CDCl}_{3}, \delta, \mathrm{ppm}\right): 167.6,152.4,144.3,133.9,132.6,127.7 .1,118.4,118.2,110.9,74.3,70.2 . \mathrm{FT}-\mathrm{IR}: 1749 \mathrm{~cm}^{-1}$ $($ 回 $\mathrm{c}=\mathrm{O})$.

$\mathrm{mPEG}_{2 \mathrm{k}}$ triallyl ether (4). Methoxypolyethylene glycol amine $2.0 \mathrm{kDa}(1.5 \mathrm{~g}, 0.75 \mathrm{mmol})$ was dissolved in toluene (50 $\mathrm{mL}$ ) and solvent was then removed under reduced pressure. This procedure was repeated five times, to remove traces of water from the PEG starting material, before starting the reaction. Compound (3) $(1.00 \mathrm{~g}, 3.20 \mathrm{mmol}, 4.2 \mathrm{eq}$.), methoxypolyethylene glycol amine $2,0 \mathrm{kDa}(1.5 \mathrm{~g}, 0.75 \mathrm{mmol}, 1.0 \mathrm{eq}$.) and anhydrous triethylamine $(0.70 \mathrm{~g}, 6.9 \mathrm{mmol}$, 9.2 eq.) were dissolved in anhydrous dichloromethane $(50 \mathrm{~mL})$ under inert atmosphere. The mixture was stirred at room temperature overnight, after which time ${ }^{1} \mathrm{H}$ NMR analysis showed that the reaction was complete (aromatics signals shifted from 7.35 to $7.04 \mathrm{ppm}$ ). The solvent was then removed under reduced pressure, and the resulting residue suspended in $60 \mathrm{~mL}$ of water. Insoluble starting material (3) and potential compounds derived from it were removed by filtration, and the aqueous solution was extracted with $\mathrm{Et}_{2} \mathrm{O}(3 \times 100 \mathrm{~mL})$ to remove triethylamine and other non-water soluble impurities, and finally with dichloromethane $(3 \times 100 \mathrm{~mL})$. Removal of the solvent from the combined organic layers gave (4) as a waxy solid (yield: $1.6 \mathrm{~g}, 92 \%) .{ }^{1} \mathrm{H} \mathrm{NMR}\left(400 \mathrm{MHz}, \mathrm{CDCl}_{3}, \delta, \mathrm{ppm}\right): 7.04(\mathrm{~s}, 2 \mathrm{H}$, $\left.\mathrm{CH}_{\text {aromatic }}\right), 6.75$ (bs, $\left.1 \mathrm{H}, \mathrm{NHCO}\right) 6.08-5.97\left(\mathrm{~m}, 3 \mathrm{H}_{\text {allyl }}\right), 5.44-5.15\left(\mathrm{~m}, 6 \mathrm{H}_{\text {allyl }}\right), 4.64-4.57(\mathrm{~m}, 6 \mathrm{H}, \mathrm{OCH}), 3.64-3.50(\mathrm{~s}, 194 \mathrm{H}$, $\mathrm{OCH}_{2}$ of PEG), 3.37 (s, $3 \mathrm{H}, \mathrm{OCH}_{3}$ of PEG).

TriaminoPEG $2 \mathrm{k}$ (5). $\mathrm{mPEG}_{2 \mathrm{k}}$ triallyl ether (4) (1.6 g, $0.69 \mathrm{mmol}, 1.0$ eq.), cysteamine hydrochloride $(0.90 \mathrm{~g}, 12 \mathrm{mmol}, 16$ eq.) and 2,2-dimethoxy-2-phenylacetophenone (DPAP) $(0.060 \mathrm{~g}, 0.23 \mathrm{mmol}, 0.3$ eq.) were dissolved in methanol (5 $\mathrm{mL}$ ). The mixture was then irradiated using a 36 Watt UV Lamp equipped with 4 X $9 \mathrm{~W}$ Light bulbs at $365 \mathrm{~nm}$ for 3 hours, until allyl signals could no longer be detected by ${ }^{1} \mathrm{H}$ NMR. Methanol was then evaporated under reduced pressure and the resulting residue was suspended in water. The mixture was extracted with ethyl acetate in order to remove traces of DPAP and corresponding decomposition products. After saturation with $\mathrm{NaCl}$ the aqueous phase was extracted with isopropanol:dichloromethane 3:1 vol:vol. Solvent removal under reduced pressure from the combined organic layers provided (5) as solid (1.5 g, 76\%). ${ }^{1} \mathrm{H} \mathrm{NMR}\left(400 \mathrm{MHz}, \mathrm{CD}{ }_{3} \mathrm{OD}, \delta, \mathrm{ppm}\right): 7.24$ (s, $2 \mathrm{H}, \mathrm{CH}_{\text {aromatic }}$ ), $4.22\left(\mathrm{t}, \mathrm{J}=6.0 \mathrm{~Hz}, 4 \mathrm{H}, \mathrm{OCH}_{2} \mathrm{CH}_{2} \mathrm{CH}_{2} \mathrm{~S}\right), 4.14\left(\mathrm{t}, \mathrm{J}=5.8 \mathrm{~Hz}, 2 \mathrm{H}, \mathrm{OCH}_{2} \mathrm{CH}_{2} \mathrm{CH}_{2} \mathrm{~S}\right), 3.85-3.50\left(\mathrm{~s}, 236 \mathrm{H}, \mathrm{OCH}_{2}\right.$ of PEG), 3.35 (s, $3 \mathrm{H}, \mathrm{OCH}_{3}$ of methoxy PEG), $3.20\left(\mathrm{t}, J=6.7 \mathrm{~Hz}, 6 \mathrm{H}, \mathrm{CH}_{2} \mathrm{~N}\right), 2.90-2.78\left(\mathrm{~m}, 12 \mathrm{H}, \mathrm{CH}_{2} \mathrm{~S}\right), 2.18\left(\mathrm{~m}, 4 \mathrm{H}, \mathrm{OCH}_{2} \mathrm{CH}_{2} \mathrm{CH}_{2} \mathrm{~S}\right), 1.97$ (m, $2 \mathrm{H}, \mathrm{OCH}_{2} \mathrm{CH}_{2} \mathrm{CH}_{2} \mathrm{~S}$ ).

p-Benzyl-L-glutamate $\mathbf{N}$-carboxyanhydride (NCA). L-Glutamic acid $\mathrm{\gamma}$-benzyl ester $(13.7 \mathrm{~g}, 57.8 \mathrm{mmol}$ ) was added to a dry round bottomed flask. Anhydrous THF $(200 \mathrm{~mL})$ and triphosgene $(6.8 \mathrm{~g}, 23 \mathrm{mmol})$ were then added under nitrogen atmosphere. The mixture was heated at 50 으 under stirring. The reaction mixture turned clear in about $1 \mathrm{~h}$. The solution was then cooled down to room temperature and bubbled with nitrogen for $2 \mathrm{~h}$ to remove traces of gaseous co-products (during this process the outlet was connected to a $\mathrm{NaOH}_{\text {aq }}$ trap). The solution was then concentrated under vacuum to a $\sim 10 \mathrm{~mL}$ volume, precipitated with petroleum ether, filtered, washed with petroleum ether and

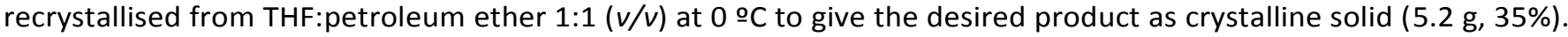


The residual mother liquor contained more $\mathrm{Y}$-benzyl-L-glutamate $\mathrm{N}$-carboxyanhydride, which however did not crystallise under these conditions. ${ }^{1} \mathrm{H}$ NMR $\left(400 \mathrm{MHz}, \mathrm{CDCl}_{3}, \delta, \mathrm{ppm}\right): 7.40-7.31(\mathrm{~m}, 5 \mathrm{H}, \mathrm{C}$ aromatic), $6.59(\mathrm{~s}, 1 \mathrm{H}, \mathrm{NH})$, $5.13\left(\mathrm{~s}, 2 \mathrm{H}, \mathrm{CH}_{2} \mathrm{O}\right), 4.38(\mathrm{ddd}, J=6.5,5.4,0.8 \mathrm{~Hz}, 1 \mathrm{H}, \mathrm{CHNH}), 2.59\left(\mathrm{t}, J=6.9 \mathrm{~Hz}, 2 \mathrm{H}, \mathrm{CH}_{2}\right), 2.31-2.06\left(\mathrm{~m}, 2 \mathrm{H}, \mathrm{CH}_{2}\right) .{ }^{13} \mathrm{C}$ NMR (101 MHz, $\left.\mathrm{CDCl}_{3}, \delta, \mathrm{ppm}\right): 172.5,169.5,151.9,135.3,128.8,128.7,128.5,67.2,57.0,30.0,27.0$. FT-IR: 1651, $1737,1790,1856$ and $1965 \mathrm{~cm}^{-1}$.

mPEG 2 -poly(glutamic acid) copolymers: typical polymerisation conditions and hydrolysis of benzyl ester repeating units. TriaminoPEG $2 \mathrm{k}$ initiator (5) $(50 \mathrm{mg}, 0.019 \mathrm{mmol})$ or commercially available methoxypolyethyleneglycol amine $2.0 \mathrm{kDa}$ $(50 \mathrm{mg}, 0.025 \mathrm{mmol})$ were dissolved in dry THF $(50 \mathrm{~mL})$ in a round bottom flask and cooled to 0 o C. $\gamma$-Benzyl-Lglutamate NCA (628 mg, $2.39 \mathrm{mmol}),(250 \mathrm{mg}, 0.940 \mathrm{mmol}),(333 \mathrm{mg}, 1.25 \mathrm{mmol})$, or (83 mg, $0.32 \mathrm{mmol})$ to form mPEG $2 k-m i k-\left(\mathrm{GA}_{30}\right)_{3}, \quad m P E G_{2 k}-m i k-\left(\mathrm{GA}_{10}\right)_{3}, \quad m P E G_{2 k}-l i n-\mathrm{GA}_{30}$, and $\mathrm{mPEG}_{2 k}$-lin-GA $\mathrm{A}_{10}$ copolymers, respectively was dissolved in anhydrous THF $(100 \mathrm{~mL})$, cooled to $0 \stackrel{\circ}{ } \mathrm{C}$ and added to the solution containing the amino-PEG initiator. The mixture was stirred in a water ice bath at 0 으 $\mathrm{C}$ under inert atmosphere. After 5 days at 0 으 $\mathrm{C}$ the conversion was found to be $\sim 70 \%$ as judged by ${ }^{1} \mathrm{H}$ NMR analysis. $6,2.35,2.35$, or $0.79 \mathrm{~mL}$ of $1.0 \mathrm{M} \mathrm{NaOH}$ aqueous solution to hydrolyse

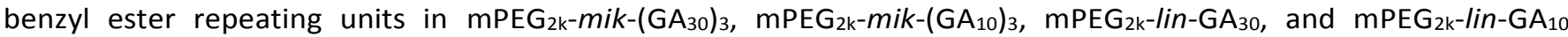
copolymers respectively, (2.5 equiv. of $\mathrm{NaOH}$ per benzyl group) were then slowly added under vigorous stirring. The reaction was left to stir for 2 days at room temperature, then the solvents were removed under reduced pressure. The residue was dissolved in distilled water $(50 \mathrm{~mL}$ ) and the resulting solution was dialysed (MWCO $1 \mathrm{kDa}$ for linear

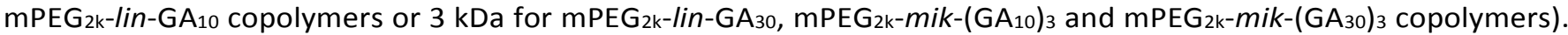
The solution was then freeze-dried and analysed by ${ }^{1} \mathrm{H}$ NMR in $\mathrm{D}_{2} \mathrm{O}$ and Size Exclusion Chromatography (SEC) using aqueous $0.10 \mathrm{M} \mathrm{NaNO}_{3}, 0.02 \mathrm{NaN}_{3}, \mathrm{pH} 10^{38}$ as the mobile phase. $\mathrm{Mn}_{n, \mathrm{NMR}}$ was calculated by comparing the integrals of the $\mathrm{OCH}_{2}$ protons of the $\mathrm{mPEG}_{2 \mathrm{k}}$ block at $3.6 \mathrm{ppm}$, and those relative to the polyGA block (see Fig. 1 for peaks assignment).

mPEG $2 \mathrm{k}-$ mik-(GA30) yield: $178 \mathrm{mg}, 60 \% .{ }^{1} \mathrm{H}$ NMR $\left(400 \mathrm{MHz}, \mathrm{D}_{2} \mathrm{O}, \delta, \mathrm{ppm}\right): 7.15$ (s, 2H, CHaromatic), 4.38-3.99 (m, 88H, $\mathrm{HNCHCO}$ and $\left.6 \mathrm{H}, \mathrm{CH}_{2} \mathrm{NH}\right), 3.70-3.47\left(\mathrm{~s}, 158 \mathrm{H}, \mathrm{OCH}_{2}\right.$ of PEG), $3.3\left(\mathrm{~s}, 3 \mathrm{H}, \mathrm{OCH}_{3}\right.$ of PEG), 3.18-2.90 (m, $\left.12 \mathrm{H}, \mathrm{CH}_{2} \mathrm{SCH}_{2}\right)$, 2.4-1.6 (m, 607H, $\mathrm{CH}_{2} \mathrm{CH}_{2} \mathrm{COOH}$ and $\left.6 \mathrm{H}, \mathrm{CH}_{2}\right) . \mathrm{Mn}_{n} \mathrm{NMR}=15.5 \mathrm{kDa}, \mathrm{MnSEC}=7.0 \mathrm{kDa}, \mathrm{Ð}=1.27$.

mPEG 2k-mik-(GA $\left._{10}\right)_{3}$ yield: $120 \mathrm{mg}, 90 \% .{ }^{1} \mathrm{H}$ NMR $\left(400 \mathrm{MHz}, \mathrm{D}_{2} \mathrm{O}, \delta, \mathrm{ppm}\right): 7.15\left(\mathrm{~s}, 2 \mathrm{H}, \mathrm{CH}_{\text {aromatic }}\right), 4.38-3.99(\mathrm{~m}, 31 \mathrm{H}$, $\mathrm{HNCHCO}$ and $\left.6 \mathrm{H}, \mathrm{CH}_{2} \mathrm{NH}\right), 3.70-3.47\left(\mathrm{~s}, 180 \mathrm{H}, \mathrm{OCH}_{2}\right.$ of PEG), $3.3\left(\mathrm{~s}, 3 \mathrm{H}, \mathrm{CH}_{3} \mathrm{O}\right.$ of $\left.\mathrm{PEG}\right), 3.18-2.90\left(\mathrm{~m}, 12 \mathrm{H}, \mathrm{CH}_{2} \mathrm{SCH}_{2}\right)$, 2.4-1.6 $\left(\mathrm{m}, 126 \mathrm{H}, \mathrm{CH}_{2} \mathrm{CH}_{2} \mathrm{COOH}\right.$ and $\left.6 \mathrm{H}, \mathrm{CH}_{2} \mathrm{NH}\right)$. $\mathrm{Mn}, \mathrm{NMR}=7.2 \mathrm{kDa}, \mathrm{Mn}, \mathrm{SEC}=4.7 \mathrm{kDa}, \mathrm{Ð}=1.28$.

mPEG $_{2 \mathrm{k}}$-lin-GA 30 yield: $140 \mathrm{mg}, 80 \% .{ }^{1} \mathrm{H}$ NMR $\left(400 \mathrm{MHz}, \mathrm{D}_{2} \mathrm{O}, \delta, \mathrm{ppm}\right): 4.38-3.99$ (m, 39H, HNCHCO), 3.70-3.47 (s, $165 \mathrm{H}, \mathrm{OCH}_{2}$ of PEG), $3.3\left(\mathrm{~s}, 3 \mathrm{H}, \mathrm{CH}_{3} \mathrm{O}\right.$ of PEG), 2.4-1.6 (m, $161 \mathrm{H}, \mathrm{CH}_{2} \mathrm{CH}_{2} \mathrm{COOH}$ ). $\mathrm{Mn}_{\mathrm{n}, \mathrm{NMR}}=7.7 \mathrm{kDa}, \mathrm{Mn}_{\mathrm{n}, \mathrm{SEC}}=1.9 \mathrm{kDa}, \mathrm{D}=$ 1.26 .

mPEG $2 \mathrm{k}-$ lin-GA 10 yield: $71 \mathrm{mg}, 81 \% .{ }^{1} \mathrm{H}$ NMR $\left(400 \mathrm{MHz}, \mathrm{D}_{2} \mathrm{O}, \delta, \mathrm{ppm}\right): 4.38-3.99(\mathrm{~m}, 14 \mathrm{H}, \mathrm{HNCHCO}), 3.70-3.47$ (s, $1770 \mathrm{H}, \mathrm{OCH}_{2}$ of PEG), $3.3\left(\mathrm{~s}, 3 \mathrm{H}, \mathrm{CH}_{3} \mathrm{O}\right.$ of PEG), 2.4-1.6 (m, 77H, $\left.\mathrm{CH}_{2} \mathrm{CH}_{2} \mathrm{COOH}\right) . \mathrm{Mnn}_{\mathrm{NMR}}=3.9 \mathrm{kDa}, \mathrm{Mn}_{\mathrm{n}, \mathrm{SEC}}=2.2 \mathrm{kDa}, \mathrm{D}=$ 1.24 .

Preparation of polymer-protein nanocomplexes. Association was assessed at different polymer-protein mixing ratios ( $r$ $=0.1,0.25,0.5,1.0,1.5,2.0$ and 2.5) where $r$ was the ratio between the number of glutamic acid residues present in the copolymer and the number of lysine and arginine residues in lysozyme. Polymer and protein stock solutions were prepared by separately dissolving them in phosphate buffer (PB, $10 \mathrm{mM}, \mathrm{pH} 7.4 ; \mathrm{Na}_{2} \mathrm{HPO}_{4} 8.1 \mathrm{mM}, \mathrm{NaH}_{2} \mathrm{PO}_{4} \cdot 2 \mathrm{H}_{2} \mathrm{O}$ $1.47 \mathrm{mM}$ ) at a concentration of $10 \mathrm{mg} \mathrm{mL}^{-1}$ and $14.5 \mathrm{mg} \mathrm{mL}^{-1}$, respectively, and appropriate aliquots mixed in order to achieve the desired $r$ values. Protein concentration was kept constant at $300 \mu \mathrm{g} \mathrm{mL}^{-1}$ in all mixing ratios, unless otherwise stated. The mixtures were stored overnight at room temperature prior to further characterisation.

Agarose gel electrophoresis. Polymer-protein complexes were prepared as described above at the same mixing ratios. Protein concentration was kept constant $(300 \mu \mathrm{g} \mathrm{mL}-1) .50 \mu \mathrm{L}$ of complexes solution were loaded onto $1 \%(w / v)$ agarose gel with $25 \mu \mathrm{L}$ of solution of $25 \mathrm{mg} \mathrm{mL}^{-1}$ ethidium bromide and the electrophoresis was ran with TRIS-acetateEDTA (TAE) buffer at $100 \mathrm{~mA}$ for 2 hours. The resulting gel was stained with Coomassie blue and visualised on an ultraviolet transilluminator. Free lysozyme and free polymers were used as controls.

To perform agarose gel electrophoresis with complexes at acid $\mathrm{pH}$, polymer-protein associations were prepared as described before using a phosphate buffer at $\mathrm{pH} 2(10 \mathrm{mM}, \mathrm{pH} 2.0)$. The procedure was the same as described before.

Nanoparticle Tracking Analysis (NTA). The hydrodynamic diameter of complexes was measured by NTA using a Nanosight LM14. All measurements were performed at $25{ }^{\circ} \mathrm{C}$. NTA 2.0 Build 127 software was used for data acquisition and analysis. The samples were measured for $80 \mathrm{~s}$. Mean size ( $\pm S D$ ) values correspond to the arithmetic values calculated for all the particles analysed by the software. Polymer-protein nanocomplexes were prepared as 
described before using ratios of 1.0 and 2.5, in phosphate buffer, $10 \mathrm{mM}, \mathrm{pH}$ 7.4. Protein concentration was kept constant $\left(70 \mu \mathrm{g} \mathrm{mL}^{-1}\right)$ for all measurements. Free protein and polymers were used as controls.

Intrinsic fluorescence spectroscopy. Protein tryptophan fluorescence spectra were measured using a Cary Eclipse Fluorescence Spectrophotometer. The excitation wavelength was $280 \mathrm{~nm}$. Slits were 5.0 and $10.0 \mathrm{~nm}$ for excitation and emission, respectively. Polymer-protein nanocomplexes were prepared as described before using a charge ratio of 2.5. Protein concentration was kept constant $\left(70 \mu \mathrm{g} \mathrm{m}^{-1}\right)$.

Circular dichroism spectroscopy. CD spectra were recorded on an Applied Photo-physics Chirascan circular dichroism spectropolarimeter using a $1 \mathrm{~mm}$ path length quartz cuvette. $\mathrm{CD}$ measurements were performed at $25^{\circ} \mathrm{C}$ over a range of 180-250 nm using a response time of $1 \mathrm{~s}, 1 \mathrm{~nm}$ pitch and $0.5 \mathrm{~nm}$ bandwidth. The recorded spectra represent a smoothed average of three scans, zero-corrected at $250 \mathrm{~nm}$ and normalized (Molar ellipticity $\theta$ is quoted in 105 deg $\left.\mathrm{cm}^{2} \mathrm{dmol}^{-1}\right)$. The absorbance of the buffer was subtracted from the recorded spectra. Polymer-protein complexes were prepared as described before using a charge ratio of $0.1,1$ and 2.5. Protein concentration was kept constant (37 $\left.\mu \mathrm{g} \mathrm{mL}{ }^{-1}\right)$.

Lysozyme enzymatic activity assay. A turbidimetric enzymatic assay was performed by measuring the decrease in optical density of an aqueous suspension of Micrococcus lysodeikticus lyophilised cells, a natural substrate for lysozyme, in PB. Polymer-protein complexes were prepared as described before at ratios 0.1, 0.5, 1.0 and 2.5. Lysozyme concentration was kept constant $\left(37 \mu \mathrm{g} \mathrm{mL}^{-1}\right)$. PB $(20 \mathrm{~mL})$ solution was added to $10 \mathrm{mg}$ of lyophilised cells. $300 \mu \mathrm{L}$ of this substrate suspension were added to $150 \mu \mathrm{L}$ of nanocomplexes solution and the decrease in optical density at $\lambda=460 \mathrm{~nm}$ was measured as a function of time. Free polymers and free lysozyme were used as controls at the same concentration as in the samples. All kinetics experiments were carried out in triplicate.

To recover lysozyme from the nanocomplexes, $480 \mu \mathrm{g}$ of poly(allyl amine) ( $\mathrm{M}_{\mathrm{w}} \sim 17 \mathrm{kDa}$, 20 wt. \% solution in $\mathrm{H}_{2} \mathrm{O}$ ) were added to $2 \mathrm{~mL}$ of the nanocomplex suspension and the resulting solution mixture was maintained under very gentle agitation for $1 \mathrm{~h}$ at room temperature. Lysozyme activity of the resulting solution was then measured as described above.

\section{Results and discussion}

\section{Synthesis of miktoarm and linear PEE $_{2 k}$-poly(glutamic acid) copolymers}

In this work, we synthesised two novel $A-B_{3}$ miktoarm star polymers consisting of one 2.0 kDa monomethoxy polyethylene glycol ( $\mathrm{mPEG}_{2 \mathrm{k}}$ ) arm (A) and three poly(glutamic acid) poly(GA) branches (B) of variable chain length. Glutamic acid repeating units were utilised here as potential binding sites for the complexation of positively charged aminoacids in protein structure.

Formation of polymer-protein complexes was expected to occur through electrostatic interactions, and be especially favoured at a pH window between the pKa of carboxylic groups of poly(glutamic acid) and the pl of the selected protein. In this work the length of the hydrophilic PPEG $_{2 k} A$ block was kept constant and that of protein-binding polyGA arms was systematically varied. Methyl 3,4,5-trihydroxybenzoate (gallic acid methyl ester) was used as the starting point to generate the core of the miktoarm polymers synthesised. Reaction with allyl bromide using potassium carbonate as a base afforded the triallyl ether $(\mathbf{1})^{39}$ in virtually quantitative yield (Scheme 1). 

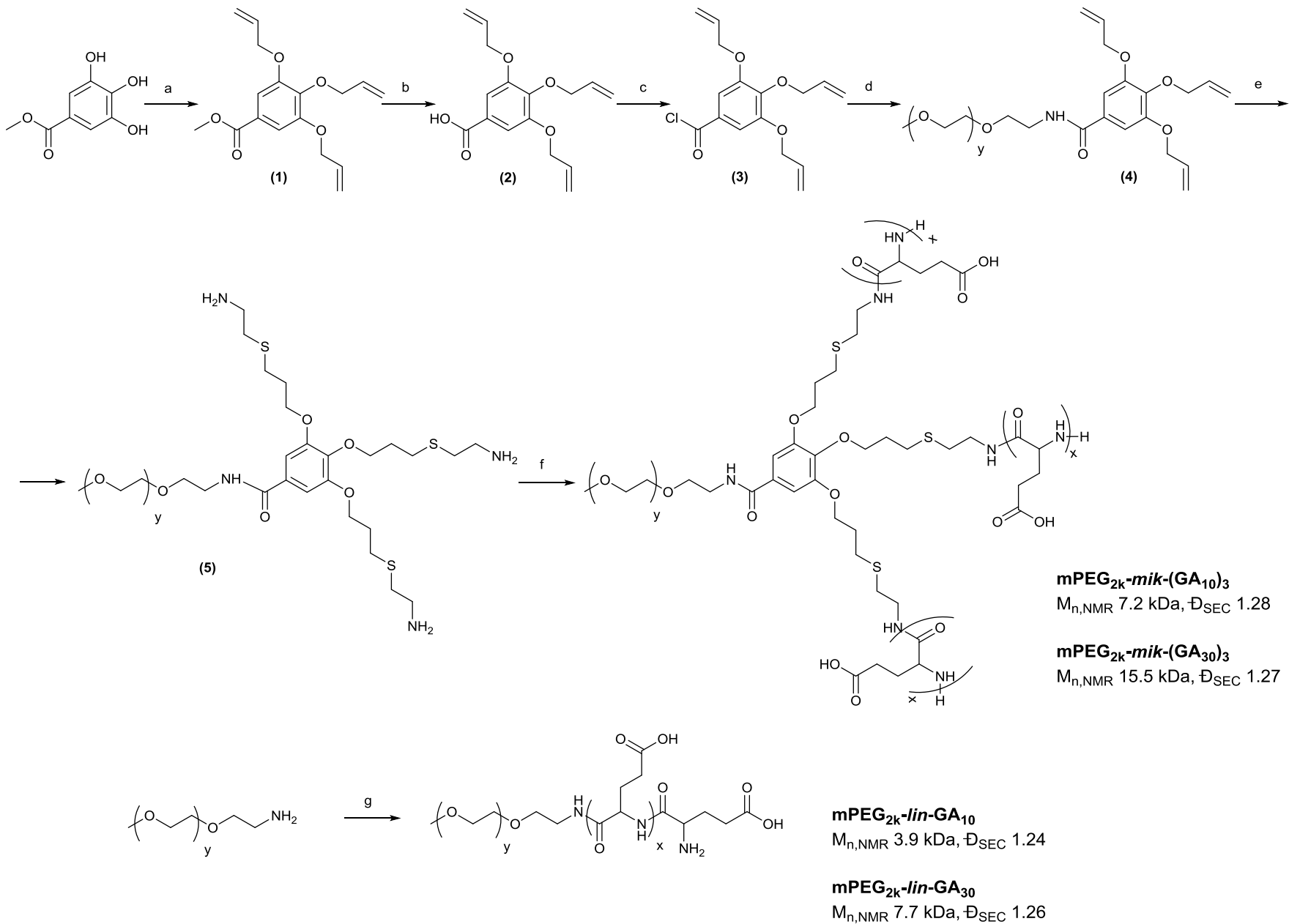

Scheme 1. Reactions and conditions. a) allyl bromide, $\mathrm{K}_{2} \mathrm{CO}_{3}$, acetonitrile, heated to reflux, $3 \mathrm{~h}$; b) $\mathrm{NaOH}, \mathrm{MeOH} / \mathrm{CH}_{2} \mathrm{Cl}, 14 \mathrm{~h}$; c) oxalyl chloride, DMF, $\mathrm{CH}_{2} \mathrm{Cl}_{2}, 1 \mathrm{~h}$; d) methoxypolyethylene glycol amine $2.0 \mathrm{kDa}$, triethylamine, $\mathrm{CH}_{2} \mathrm{Cl}_{2}$, overnight; e) cysteamine hydrochloride, DPAP, MeOH, UV, 3 h; f) and g) 1) $p$-benzyl-L-glutamate NCA, THF, 0 으, 5 days and 2) $\mathrm{NaOH}, \mathrm{H}_{2} \mathrm{O} / \mathrm{THF}, 2$ days.

Hydrolysis of (1) with methanolic $\mathrm{NaOH}$ gave the acid (2) which was then converted in its correspondent acid chloride (3) with oxalyl chloride, using DMF as the catalyst. Whilst both ${ }^{1} \mathrm{H}$ and ${ }^{13} \mathrm{C}$ NMR analyses were found not suitable to differentiate between (2) and (3), FT-IR showed the disappearance of the band at $1687 \mathrm{~cm}^{-1}$ for the acid moiety of (2), and the appearance of a new band at $1749 \mathrm{~cm}^{-1}$ of the $C=O$ stretching of the acid chloride group of (3). The latter was then reacted with methoxypolyethylene glycol amine $2.0 \mathrm{kDa}$ in anhydrous dichloromethane using triethylamine as the acid scavenger (4). Thiol-ene ${ }^{40}$ addition in the presence of cysteamine hydrochloride and 2,2-dimethoxy-2phenylacetophenone (DPAP) photoinitiator under irradiation at $\lambda=365 \mathrm{~nm}$ in methanol for 3 hours gave the desired $\mathrm{mPEG}_{2 \mathrm{k}}$-triamino initiator (5). Quantitative conversion of triallyl $\mathrm{mPEG}_{2 \mathrm{k}}$ (4) into (5) was achieved after careful optimisation of the thiol-ene reaction conditions, especially in terms of amount of solvent required, alkyne:photoinitiator molar ratio, and reaction time.

Polymerisation of $\alpha$-amino acid- $N$-carboxyanhydrides (NCAs) has emerged in recent years as one of the most efficient and versatile routes to synthetic homopolypeptides. The polymerisation requires a nucleophilic initiator, typically a primary amine and proceeds by sequential nucleophilic ring-opening of the monomer(s) NCA ring, affording welldefined polymers with low polydispersities provided that side reactions are minimised.$^{41}$ Loss of control can occur via several mechanisms. For example, dry conditions are essential as water can act as an initiator and start the 
polymerisation process. Habraken et al. showed that NCA polymerisation at 0 -C leads to poly(glutamic acid) with very high fidelity in amino-end groups required to achieve control over the polymerisation process, leading to well-defined polymers with low polydispersities. However, at higher temperatures pyroglutamates end-groups were generated, leading to unwanted chain termination and broader molecular weight distributions. ${ }^{42}$

In the present study, a family of $\mathrm{mPEG}_{2 \mathrm{k}}$-poly $(\mathrm{GA})$ copolymers with linear and miktoarm macromolecular structures was prepared from initiators (5) and $\mathrm{mPEG}_{2 k} \mathrm{NH}_{2}$, respectively. The number of glutamic acid (GA) monomer units in $B$ block arms were either 10 or 30 in both linear and miktoarm polymers (Table 1).

Table 1. Composition, architecture, $\mathrm{M}_{n}$, and polydispersity of $\mathrm{mPEG}_{2 \mathrm{k}}$-polyGA copolymers prepared in this study.

\begin{tabular}{|c|c|c|c|c|c|}
\hline Polymer & Architecture & $\begin{array}{l}M_{n, \text { Theo }} \\
(\mathrm{kDa})^{\mathrm{a}}\end{array}$ & $\begin{array}{l}M_{\mathrm{n}, \mathrm{NMR}} \\
(\mathrm{kDa})^{\mathrm{b}}\end{array}$ & $\begin{array}{l}M_{n, S E C} \\
(k D a)^{c}\end{array}$ & $\bigoplus_{\mathrm{SEC}}^{\mathrm{c}}$ \\
\hline $\mathrm{mPEG}_{2 \mathrm{k}}-m i k-\left(\mathrm{GA}_{10}\right)_{3}$ & miktoarm & 7.0 & 7.2 & 4.7 & 1.28 \\
\hline$m P E G_{2 k}-m i k-\left(\mathrm{GA}_{30}\right)_{3}$ & miktoarm & 14.8 & 15.5 & 7.0 & 1.27 \\
\hline $\mathrm{mPEG}_{2 \mathrm{k}}-\mathrm{lin}-\mathrm{GA}_{10}$ & linear & 3.3 & 3.9 & 2.2 & 1.24 \\
\hline $\mathrm{mPEG}_{2 \mathrm{k}}-\operatorname{lin}-\mathrm{GA}_{30}$ & linear & 7.1 & 7.7 & 1.9 & 1.26 \\
\hline
\end{tabular}

a Calculated from [Monomer $]_{0} /[\text { Initiator }]_{0}$ and conversion values for each polymerisation run; ${ }^{\mathrm{b}}$ Copolymers composition estimated by ${ }^{1 \mathrm{H}}$ NMR in $\mathrm{D}_{2} \mathrm{O}$. ' Determined by SEC in aqueous $0.10 \mathrm{M} \mathrm{NaNO}_{3}, 0.02(\mathrm{w} / \mathrm{v}) \mathrm{NaN}_{3}, \mathrm{pH} 10.0$ as the mobile phase, ${ }^{38}$ in a system calibrated with $0.2-130 \mathrm{kDa}$ PEO standards.

Linear $\mathrm{mPEG}_{2 \mathrm{k}}$-lin- $\mathrm{GA}_{10}$ and $\mathrm{mPEG}_{2 \mathrm{k}}$-lin- $\mathrm{GA}_{30}$ copolymers were synthesised using commercially available monoamino $\mathrm{mPEG}_{2 \mathrm{k}}(2.0 \mathrm{kDa})$ as the polymerisation initiator, whilst for miktoarm mPEG $2 \mathrm{k}$-mik-poly $(\mathrm{GA})_{3}$ copolymers a trifunctional initiator (5) was required. All polymerisation reactions were carried out at $0^{\circ} \mathrm{C}$ and monitored by ${ }^{1} \mathrm{H} N M R$, by following the disappearance of the $\alpha-\mathrm{CH}$ proton signal of the NCA monomer at $4.4 \mathrm{ppm}$. The polymerisations were stopped at $\sim 70 \%$ conversion, which generally occurred within 5 days.

Treatment of the reaction crude product with $\mathrm{NaOH}_{a q}$ afforded the required $\mathrm{mPEG}_{2 \mathrm{k}}$-polyGA copolymers, which were purified by dialysis against deionised water (MWCO 1-3 kDa).

A typical ${ }^{1} \mathrm{H}$ NMR spectrum of a $\mathrm{mPEG}_{2 \mathrm{k}}$-poly(GA) copolymer is shown in Fig. 1. Mn,NMR were calculated by comparing the integral of the ethylene repeating units of $\mathrm{mPEG}_{2 \mathrm{k}}$ with that of the $\mathrm{CHN}$ groups in the glutamic acid repeating units, and were found to be in good agreement with the theoretical ones, calculated from the initial (mPEG $2 \mathrm{k}$ initiator):(glutamic acid $\mathrm{N}$-carboxyanhydride monomer) molar ratios and the final monomer conversions.

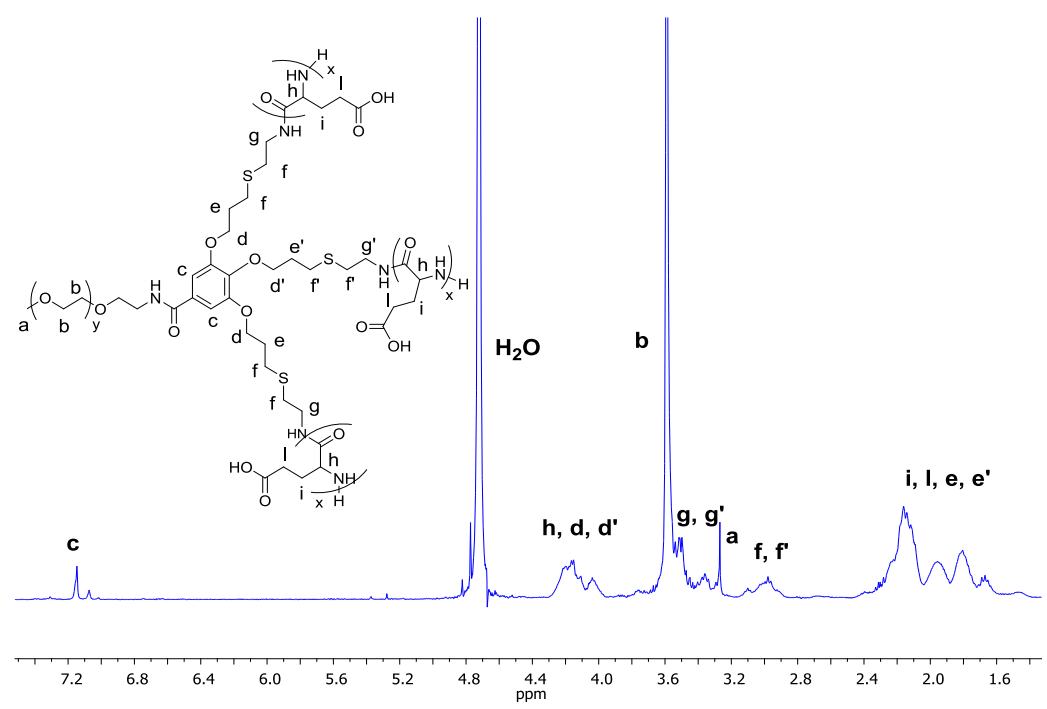

Fig. $1^{1} \mathrm{H}$ NMR spectrum of miktoarm $\mathrm{mPEG}_{2 \mathrm{k}}-m i k-\left(\mathrm{GA}_{10}\right)_{3}$ in $\mathrm{D}_{2} \mathrm{O}$.

${ }^{1} \mathrm{H}$ NMR confirmed that the $\mathrm{MnnMR}_{n, \mathrm{NM}}$ of all copolymers was in line with the expected theoretical values (Table 1$)$. SEC analysis using SEC aqueous $0.10 \mathrm{M} \mathrm{NaNO}_{3}, 0.02(\mathrm{w} / \mathrm{v}) \mathrm{NaN}_{3}, \mathrm{pH} 10^{38}$ showed a lower average molecular mass $\mathrm{M}_{n, \mathrm{SEC}}$ which could be ascribed to the difference in relative hydrodynamic diameter between $\mathrm{mPEG}_{2 \mathrm{k}}$ - polyGA and $\mathrm{mPEG}$ narrow standards used to calibrate the SEC. 


\section{Polymer-protein complexes characterisation}

Next, the ability of $\mathrm{MPEG}_{2 \mathrm{k}}$-polyGA copolymers to complex model protein, lysozyme, was assessed. Hen egg-white lysozyme is a 129 aminoacid, $14.3 \mathrm{kDa}$ protein $^{43}$ with isoelectric point at $\mathrm{pH} 11.3,{ }^{44}$ with 6 lysine and 11 arginine residues $^{45}$ exposed at the surface of the protein. This enzyme has a net positive charge $(+7.5)$ at physiological $\mathrm{pH}^{46}$ which potentially could allow its complexation with polyanionic macromolecules.

In this study polymer:protein complexes were studied by incubating mPEG $2 k$-polyGA copolymers and lysozyme in 10 $\mathrm{mM}$ phosphate buffer, $\mathrm{pH} 7.4$ or $\mathrm{pH}$ 2.0. Association was assessed in the 0.1-2.5 range of mixing ratios $r$, defined as the relative molar charge ratio between the number of glutamic acid monomer units in $\mathrm{mPEG}_{2 \mathrm{k}}$-polyGA copolymers (mostly negatively charged at pH 7.4), and the number of lysine and arginine residues in the lysozyme (positively charged at both $\mathrm{pH} 7.4$ and 2.0).

Poly(glutamic acid) possesses mostly a $\alpha$-helix conformation ( 3.6 residues per turn) at $\mathrm{pH}<5$, in aqueous media, whilst at $\mathrm{pH}>6$ it exhibits a random coil conformation. ${ }^{47}$ This coil-to-helix conformation transition depends on different factors, including $\mathrm{pH}$, chain length, concentration and temperature. ${ }^{48,49} \mathrm{At} \mathrm{pH} 7.4$ poly(GA) is expected to assume mostly a random coil conformation due to Coulombic repulsion between ionised glutamate sidechains, ${ }^{49}$ thus potentially further favouring protein complexation. The protein concentration was kept constant (300 $\left.\mathrm{gg} \mathrm{mL}^{-1}\right)$, whilst the polymer concentration was varied to obtain the desired $r$ values.

A) $\mathrm{pH}: 2.0$
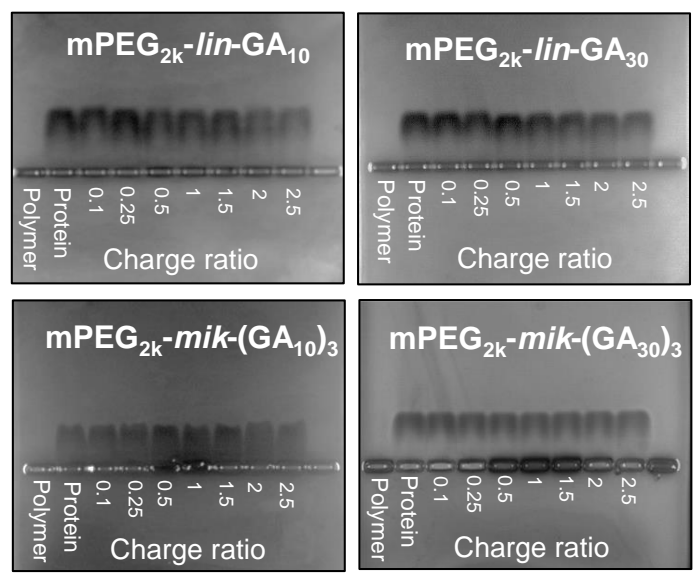

B) $\mathrm{pH}: 7.4$
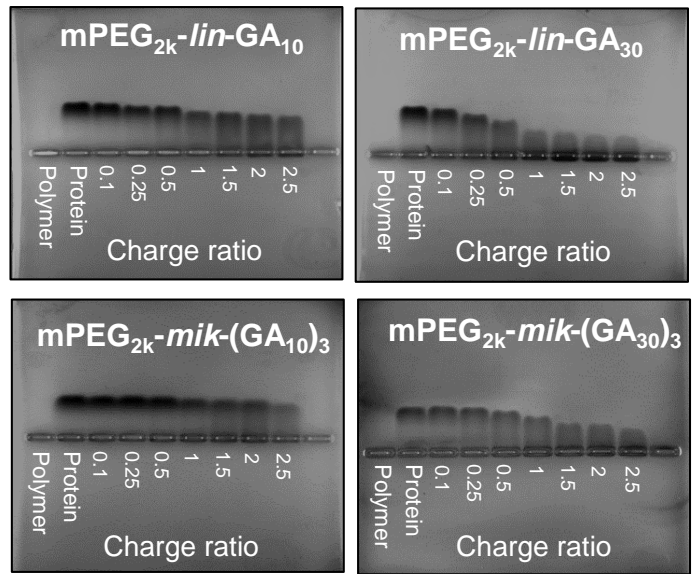

Fig. 2 Electrophoretic mobility at pH 2.0 (A) and pH 7.4 (B) of lysozyme from protein complexes with linear $\mathrm{mPEG}_{2 \mathrm{k}}-\mathrm{lin}-\mathrm{GA}_{10}$ and mPEG $2 \mathrm{k}-$ lin- $\mathrm{GA}_{30}$, and miktoarm $\mathrm{mPEG}_{2 \mathrm{k}}-$ mik- $\left(\mathrm{GA}_{10}\right)_{3}$ and $\mathrm{mPEG}_{2 \mathrm{k}}-$ mik- $\left(\mathrm{GA}_{30}\right)_{3}$-derived complexes in a $1 \%$ agarose gel, run $2 \mathrm{~h}$ at 100 $m A$ in Tris-Acetate-EDTA buffer.

Protein complexation was first assessed by agarose gel electrophoresis in an electrophoretic mobility shift assay (Fig. 2). The efficiency of protein-(mPEG $2 \mathrm{k}-$ polyGA) complexation was found to be $\mathrm{pH}$-dependent, with no complexation 
observed at pH 2.0 (Fig. 2A), where carboxylic groups of the glutamic acid repeating units exist in their protonated uncharged form, and are hence unable to engage with positively charged Lys and Arg protein residues. Taken together with evidence of protein-(mPEG $2 \mathrm{k}$-polyGA) complexation under pH 7.4 conditions (Fig. 2B) these results further confirm that the complexation process was indeed driven by ionic interactions between the species. The $\mathrm{pH} 7.4 \mathrm{gels}$ followed a general pattern, where bands were observed at low $r$ ratios, indicating the presence of either weakly complexed, or free protein. As the amount of copolymer increased at higher $r$ ratios, the free protein bands gradually became dimmer, indicating greater level of complexation with the copolymer, until they eventually disappear. At higher $r$ ratios increased staining could be seen in the wells, which was suggestive of the presence of large and/or of neutral or negatively charged complexes which prevented their migration out of the well.

A)

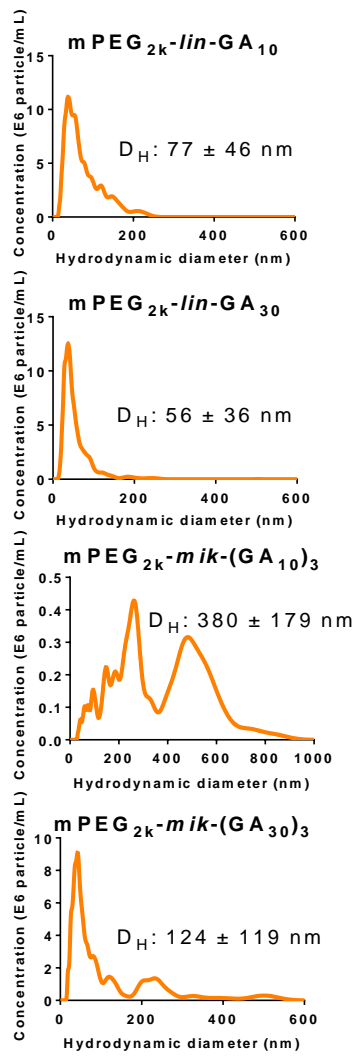

B)

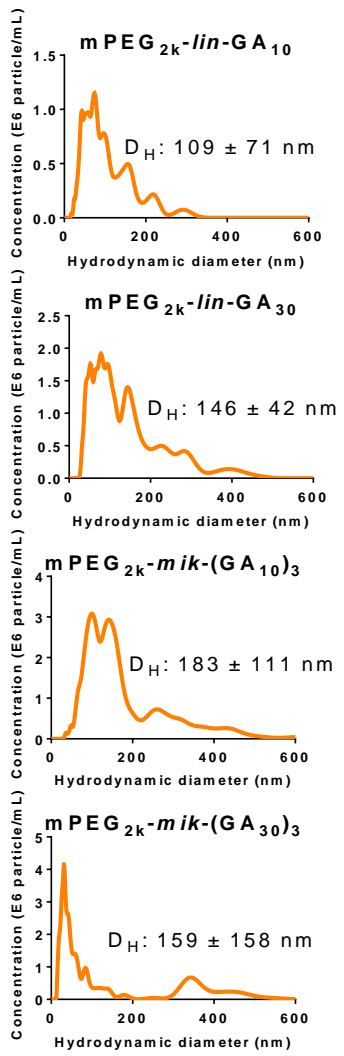

Fig. 3 Particle size distribution of $\mathrm{mPEG}_{2 \mathrm{k}}-$ lin- $\mathrm{GA}_{10}, \mathrm{mPEG}_{2 \mathrm{k}}-\mathrm{lin}-\mathrm{GA}_{30}, \mathrm{mPEG}_{2 \mathrm{k}}$-mik- $\left(\mathrm{GA}_{10}\right)_{3}$ and $m \mathrm{mEG}_{2 \mathrm{k}}-\mathrm{mik}-\left(\mathrm{GA}_{30}\right)_{3}$-derived complexes with lysozyme at charge ratio 1.0 (A) and 2.5 (B). $D_{H}$ is the average hydrodynamic diameter \pm SD of polymer-protein nanocomplexes as assessed by nanoparticle tracking analysis (NTA).

These results suggested a dependence of protein complexation on the molecular composition and architecture of the complexing copolymer. Low level of complexation was found for linear $\mathrm{mPEG}_{2 \mathrm{k}}$-lin-GA $\mathrm{A}_{10}$ which was not significantly improved by the use of a miktoarm $\mathrm{mPEG}_{2 \mathrm{k}}-$ mik- $\left(\mathrm{GA}_{10}\right)_{3}$ copolymer, containing three arms of $\mathrm{GA}_{10}$. Intriguingly, the same number of GA monomeric units (30) but arranged in a linear chain of mPEG 2 -lin-GA 30 copolymer produced a superior complexation whereby, from approximately $r \geq 1.0$, no free protein could be observed in the gel. Further increase in the number of $\mathrm{GA}_{30}$ branches in $\mathrm{mPEG}_{2 \mathrm{k}}-\mathrm{mik}-\left(\mathrm{GA}_{30}\right)_{3}$ miktoarm resulted in a gel pattern similar to that observed for $\mathrm{mPEG}_{2 \mathrm{k}}$-lin-GA30.

The particle size of lysozyme-(mPEG $2 k-$ polyGA) complexes at 1.0 and 2.5 ratios were analysed by nanoparticle tracking analysis (NTA). In the present study, NTA was found to be superior to dynamic light scattering (DLS) to estimate the size of relatively polydisperse samples of polymer:protein complexes in suspension, as reported previously. ${ }^{50}$ For $r=$ 2.5 all lysozyme-(mPEG 2 -polyGA) complexes were found to possess average diameter in the 50-200 nm range (Fig. 3)

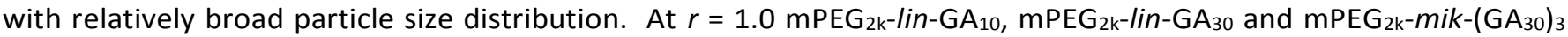
copolymers showed a hydrodynamic diameter between 50 and $150 \mathrm{~nm}$ whilst the presence of larger polymer-protein

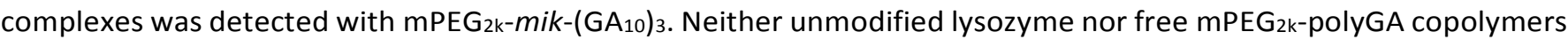


could be detected by NTA, further confirming that the sizes analysed were polymer:protein complexes. TEM images of representative lysozyme-(mPEG $2 \mathrm{k}-$ lin-GA 30$)$ complexes at $r=2.5$ (ESI Fig. S22) illustrate the presence of numerous complexes in the size range of $30-50 \mathrm{~nm}$, as well as existence of some larger species, probably aggregates.

Taken together, agarose gel electrophoresis, particle size analysis and TEM suggest that binding of the copolymers to lysozyme initiated 'controlled assembly' into complexes made of multiple molecules of lysozyme and copolymers. This agrees with previous work where $\mathrm{mPEG}_{12 \mathrm{k}-\text {-lin-Asp }} \mathrm{p}_{18}$ copolymers were utilised to form stable lysozyme complexes consisting of 36 and 42 molecules of lysozyme and mPEG-b-poly(Asp), respectively. ${ }^{12}$ One could propose that the presence of $\mathrm{PEG}_{2 \mathrm{k}}$ may prevent higher order aggregation of protein-( $\mathrm{MPEG}_{2 \mathrm{k}}-b$-polyGA) complexes when their overall charge is close to neutral, as previously suggested for $\mathrm{mPEG}_{5 \mathrm{k}}-b$-poly $(N, N$-dimethylaminoethyl methacrylate) (PAMA) copolymer when complexing L-asparaginase. ${ }^{51}$

Current literature indicates that protein binding efficiency and size of the resulting ionic complexes depend on a complex interplay between a number of parameters, including size and charge density of both polymers and proteins, $\mathrm{pH}$, ionic strength, [polymer]:[protein] molar ratio, and, for PEG-containing block copolymers, the relative size of PEG and polyionic blocks. Under the complexation conditions of the present work $(\mathrm{pH}>6)$, random coil conformation of polyglutamic acid chain would be expected, as discussed above, to allow for its relative conformational freedom in interaction with surface groups of lysozyme, however it is not clear at this point if the chain would have such a flexibility to as to 'wrap around' the protein to form multiple interactive contacts. ${ }^{52}$ The superior complexation of linear $\mathrm{GA}_{30}$ relative to both linear poly $\mathrm{GA}_{10}$ and miktoarm poly $\left(\mathrm{GA}_{10}\right)_{3}$ copolymers might be pointing to such a 'wrapping' and formation of multiple contacts as the chain length is increased. Positively charged aminoacid residues of lysozyme appear distributed throughout the protein surface ${ }^{53}$ rather than creating 'charged patches'; this may favour creation of interactive contacts with polyGA 30 linear chain of $\mathrm{MPEG}_{2 k}-\mathrm{lin}_{-} \mathrm{GA}_{30}$ rather than 'grouped' anion charges in miktoarm $\mathrm{mPEG}_{2 \mathrm{k}}-\mathrm{mik}_{\mathrm{k}}\left(\mathrm{GA}_{10}\right)_{3}$.

\section{Lysozyme conformation in protein-polymer complexes: intrinsic fluorescence studies}

Protein intrinsic fluorescence studies were carried out to investigate whether the conformation of lysozyme was affected by polymer complexation. Selected fluorescence spectra of polymer-protein complexes at a 2.5 ratio are shown in Fig. 4. Spectra are dominated by tryptophan fluorescence due to the presence of six tryptophan residues Trp-28, Trp-62, Trp-63, Trp-108, Trp-111 and Trp-123 - within the lysozyme structure. The maximum of fluorescence emission $\lambda_{\max }$ of tryptophan-containing native proteins typically falls in the 308-350 $\mathrm{nm}$ range, the exact position depending on burial of individual tryptophan residues within protein domains. Protein unfolding typically results in exposure of tryptophan residues to more polar and solvent exposed local environments, leading to a red shift of fluorescence $\lambda_{\max }$, typically in the $345-355 \mathrm{~nm}$ range. ${ }^{54}$ At $25{ }^{\circ} \mathrm{C}$ native lysozyme in $10 \mathrm{mM}$ phosphate buffer, $\mathrm{pH} 7.4$ showed a maximum emission at $\lambda=344 \mathrm{~nm}$. However, upon heating at $95{ }^{\circ} \mathrm{C}$ for $120 \mathrm{~min}, \lambda_{\max }$ shifted to $350 \mathrm{~nm}$. This bathochromic shift has been observed before, and was ascribed to unfolding of lysozyme. ${ }^{55,56}$ For (mPEG $2 k$-polyGA)lysozyme complexes, a slight hypsochromic (blue) shift of $\lambda_{\max }$ was observed, irrespective of the polymer macromolecular architecture and length of polyGA protein-binding arm(s), suggesting that upon complexation lysozyme did not unfold (Fig. 4). This blue shift may indicate that within these complexes tryptophan residues were actually exposed to a more apolar environment. ${ }^{56}$

Circular dichroism experiments on polyGA-lysozyme-(mPEG 2k-polyGA) complexes (ESI Fig. S21) proved less informative due to significant overlap between the spectra of the poly(glutamic acid) moiety and lysozyme. Although not conclusive, the data however indicated that, at least for low polymer:protein ratios, no detectable protein unfolding occurred, which is in agreement with the intrinsic tryptophan fluorescence results. 

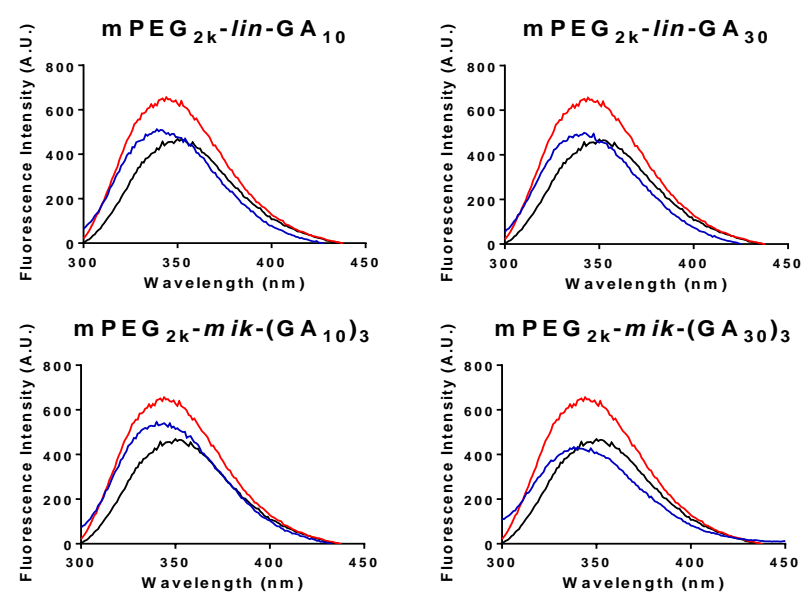

Fig. 4 Tryptophan fluorescence spectra of lysozyme after complexation with linear $m P E G_{2 k}-l i n-G_{10}$ and $m P E G_{2 k}-l i n-G A_{30}$, and miktoarm mPEG $2 \mathrm{k}-$ mik- $\left(\mathrm{GA}_{10}\right)_{3}$ and $\mathrm{mPEG}_{2 \mathrm{k}}-$ mik- $\left(\mathrm{GA}_{30}\right)_{3}$ copolymers at charge ratio 2.5 in $10 \mathrm{mM}$ phosphate buffer pH 7.4. Polymerprotein complexes (blue), native lysozyme (red) and denatured protein (black). All spectra recorded at room temperature.

\section{Lysozyme activity assay}

Lysozyme exerts its antimicrobial activity by selectively cleaving $\beta-1,4$-glycosidic bonds between $N$-acetylmuramic acid and $\mathrm{N}$-acetylglucosamine, found in bacterial cell walls. ${ }^{57}$ The effect of protein complexation on the residual enzymatic activity of lysozyme at various protein:polymer ratios was assessed using Micrococcus lisodeikticus lyophilised cell walls at the substrate. For all mPEG ${ }_{2 k}$-polyGA investigated, lytic activity decreased after polymerprotein complexation (Fig. 5) suggesting that enzyme was located within the interior of these assemblies, where the enzyme active centre was less accessible. ${ }^{58} \mathrm{~A}$ decrease in lytic activity due to protein denaturation, ${ }^{59}$ or changes in its secondary structure seemed unlikely, given the results from our intrinsic fluorescence studies. Similar decrease in lysozyme enzymatic activity was seen in complexation with polyanionic poly(acrylic acid). ${ }^{60}$

A more pronounced decrease in lysozyme activity at higher polymer:protein ratios suggests an increased complexation level (Fig. 5), which can supported by gel electrophoresis data showing more pronounced protein sequestration at higher polymer:protein ratios (Fig. 2B). (mPEG ${ }_{2 k}-$ lin-GAз)-lysozyme complexes showed the highest reduction in enzymatic activity, again indicating the importance of copolymer architecture and the length of proteinbinding polyGA moiety on sheltering of the enzyme catalytic pocket.

For comparative purposes, irreversible covalent PEGylation of lysozyme was carried out using methoxy $P_{2} G_{2 k}$ succinimidyl carbonate to generate conjugates with average number of mPEG chains ranging from 5.2-6.3 per lysozyme macromolecule. These conjugates were found to possess minimal or no residual enzymatic activity, as confirmed by Micrococcus lisodeikticus turbidimetric assay (see ESI Fig. S24). This is in agreement with previous work, which indicated that some lysine residues - e.g. Lys 97 - are located in a region responsible for substrate specificity. ${ }^{61}$ 
A
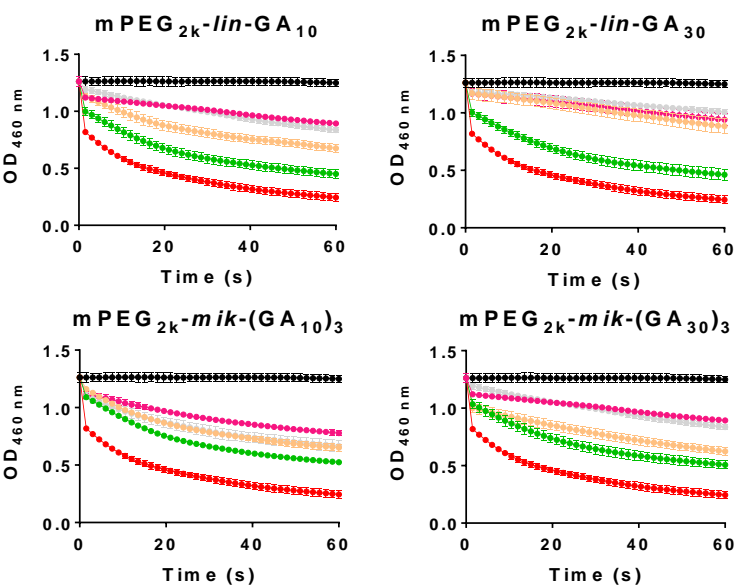

B

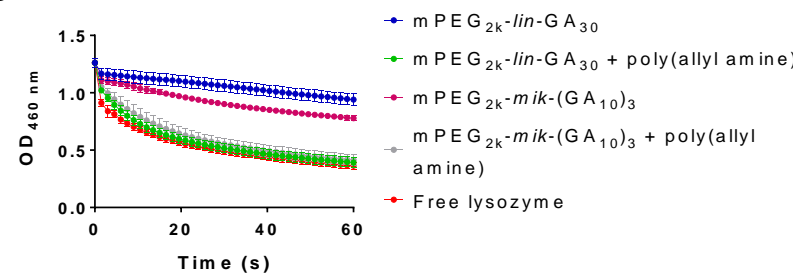

Fig. 5 A. Lysozyme enzymatic activity of linear $\mathrm{mPEG}_{2 \mathrm{k}}-$ lin- $\mathrm{GA}_{10}$ and $\mathrm{mPEG}_{2 \mathrm{k}}-$ lin- $\mathrm{GA}_{30}$, and miktoarm $\mathrm{mPEG}_{2 \mathrm{k}}-\mathrm{mik}-\left(\mathrm{GA}_{10}\right)_{3}$ and $\mathrm{mPEG}_{2 \mathrm{k}}-$ mik- $\left(\mathrm{GA}_{30}\right)_{3}$-derived complexes $(\mathrm{n}=3)$. Free protein (red), free polymer (black), and 0.1 (green), 0.5 (orange), 1.0 (grey) and 2.5 (pink) polymer:protein charge ratio $r$. OD $460 \mathrm{~nm}$ represents the optical density of the samples at $\lambda=460 \mathrm{~nm}$. B. Lysozyme enzymatic activity of selected complexes at polymer-protein charge ratio of 2.5 - with either linear $\mathrm{mPEG}_{2 \mathrm{k}}$-lin-GA $\mathrm{A}_{30}$, and miktoarm $\mathrm{mPEG}_{2 \mathrm{k}}-$ mik- $\left(\mathrm{GA}_{10}\right)_{3}$ - before and after polymer decomplexation by addition of poly(allyl amine) $(240 \mu \mathrm{g} \mathrm{mL}-1,4.2 \mathrm{mM}$ of protonable amino groups).

By contrast to PEG-conjugated lysozyme, full enzymatic activity was recovered upon de-complexation of lysozyme from the protein-(mPEG 2 -polyGA) nanocomplexes by addition of $17 \mathrm{kDa}$ poly(allyl amine), a known complexant for polyanionic polymers ${ }^{60}$ (Fig. 5B). Thus, this data confirmed that initial decrease of enzymatic activity was indeed due to inclusion of lysozyme within polymer nanocomplexes which limited the accessibility of its catalytic pocket, whereby subsequent complete recovery of activity clearly indicate that polymer complexation induced no irreversible protein unfolding or denaturation confirming this advantage of the complexation approach adopted.

\section{Conclusions}

In this work a family of PEG-polyanion copolymers suitable for non-covalent and reversible complexation of proteins is presented. $\mathrm{mPEG}_{2 \mathrm{k}}$-poly(glutamic acid) copolymers with different architecture, linear A-B and miktoarm A-B 3 , and different length of the protein-binding arms were synthesised by NCA polymerisation, and their ability to bind model protein (lysozyme) was investigated.

Electrophoresis and nanoparticle tracking analysis indicated that the length of protein-binding poly(glutamic acid) arms of the copolymers, as well as their macromolecular architecture had a significant effect on complexation efficiency, where for copolymers with the same number of glutamic acid repeating units, polymers with linear architecture were more efficient, than their miktoarm analogues, to complex lysozyme model protein.

Importantly, upon polymer complexation the protein structural conformation appears to be conserved, and no detectable denaturation was observed. Enzymatic activity of the complexed protein was reduced, attributable to limited access of substrate to enzyme active site, and the extent of this reduction depends on the macromolecular architecture of the complexing copolymer. 
Ultimately, this study identified a first structure-function relationship for a new family of $m P E_{2 k}-p$ (glutamic acid) polymers with various macromolecular architecture. Ongoing studies are focusing on utilising these findings to engineer protein therapeutics deliver systems.

\section{Acknowledgements}

Vectura Group plc and the School of Pharmacy at the University of Nottingham are acknowledged for funding A NietoOrellana's PhD studentship.

Nanoscale \& Microscale Research Center (NMRC) is also acknowledged for providing the facilities for NTA analysis.

\section{Notes and references}

${ }^{a}$ School of Pharmacy, University of Nottingham, UK.

e-mails: giuseppe.mantovani@nottingham.ac.uk; snow.stolnik@nottingham.ac.uk;

Fax : +44 (0)115 8466296 ; Tel : +44 (0)0115 8232348.

${ }^{b}$ Department of Chemistry, University of Cambridge, UK.

${ }^{c}$ Vectura Group plc, Chippenham, UK.

M. L. Tan, P. F. Choong and C. R. Dass, Peptides, 2010, 31, 184-193.

M. P. Baker, H. M. Reynolds, B. Lumicisi and C. J. Bryson, Self Nonself, 2010, 1, 314-322.

M. C. Manning, K. Patel and R. T. Borchardt, Pharm. Res., 1989, 6, 903-918.

A. Mero, O. Schiavon, G. Pasut, F. M. Veronese, E. Emilitri and P. Ferruti, J. Bioact. Compatible Polym., $2009,24,220-234$.

F. M. Veronese, Biomaterials, 2001, 22, 405-417.

D. Pfister and M. Morbidelli, J. Control. Release, 2014, 180, 134-149.

W. R. Gombotz and D. K. Pettit, Bioconjug. Chem., 1995, 6, 332-351.

S. Salmaso, S. Bersani, F. Mastrotto, G. Tonon, R. Schrepfer, S. Genovese and P. Caliceti, J. Controlled Release, $2012,162,176-184$.

E. Ambrosio, M. Barattin, S. Bersani, S. Shubber, S. Uddin, C. F. van der Walle, P. Caliceti and S. Salmaso, J. Controlled Release, 2016, 226, 3546.

S. Salmaso, S. Bersani, A. Scomparin, A. Balasso, C. Brazzale, M. Barattin and P. Caliceti, J. Controlled Release, $2014,194,168-177$.

P. M. Antonik, A. M. Eissa, A. R. Round, N. R. Cameron and P. B. Crowley, Biomacromolecules, 2016, 17, $2719-2725$.

A. Harada and K. Kataoka, Macromolecules, 1998, 31, 288-294.

M. Harada-Shiba, K. Yamauchi, A. Harada, I. Takamisawa, K. Shimokado and K. Kataoka, Gene Ther., 2002, 9, $407-414$.

D. Tsiourvas, Z. Sideratou, N. Sterioti, A. Papadopoulos, G. Nounesis and C. M. Paleos, J. Colloid Interface Sci., 2012, 384, 61-72.

G. Coue and J. F. Engbersen, J. Control. Release, 2011, 152, 90-98.

A. L. Z. Lee, Y. Wang, W.-H. Ye, H. S. Yoon, S. Y. Chan and Y.-Y. Yang, Biomaterials, 2008, 29, 1224-1232.

R. Hourani and A. Kakkar, Macromol. Rapid Commun., 2010, 31, 947-974.

C. J. Hawker, Angewandte Chemie International Edition in English, 1995, 34, 1456-1459.

K. Khanna, S. Varshney and A. Kakkar, Polymer Chemistry, 2010, 1, 1171.

I. L. Shih, Y. T. Van and M. H. Shen, Mini Rev. Med. Chem., 2004, 4, 179-188.

M. P. Melancon and C. Li, Mol. Imaging, 2011, 10, 28-42.

T. Ng, J. Fontaine, M. Suntharalingam, T. Dipetrillo, M. N. Horiba, N. B. Oldenburg, K. Perez, W. Chen, F. Habr and H. Safran, J. Clin. Oncol., $2010,28,4085-4085$.

T. Dipetrillo, M. Suntharalingam, T. Ng, J. Fontaine, N. Horiba, N. Oldenburg, K. Perez, A. Birnbaum, R. Battafarano, W. Burrows and H. Safran, Am. J. Clin. Oncol., 2012, 35, 64-7.

P. Sabbatini, M. W. Sill, D. O'Malley, L. Adler and A. A. Secord, Gynecol. Oncol., 2008, 111, 455-460.

M. A. Morgan, K. M. Darcy, P. G. Rose, K. DeGeest, M. A. Bookman, J. K. Aikins, M. W. Sill, R. S. Mannel, C. Allievi and M. J. Egorin, Gynecol. Oncol., 2008, 110, 329-335.

M. E. R. O'Brien, M. A. Socinski, A. Y. Popovich, I. N. Bondarenko, A. Tomova, B. T. Bilynsky`1, Y. S. Hotko, V. L. Ganul, I. Y. Kostinsky, A. J. Eisenfeld, L. Sandalic, F. B. Oldham, B. Bandstra, A. B. Sandler and J. W. Singer, J. Thorac. Oncol., $2008,3,728-734$.

K. S. Albain, C. P. Belani, P. Bonomi, K. J. O'Byrne, J. H. Schiller and M. Socinski, Clin. Lung Cancer, $2006,7,417-419$.

L. Paz-Ares, H. Ross, M. O'Brien, A. Riviere, U. Gatzemeier, J. Von Pawel, E. Kaukel, L. Freitag, W. Digel, H. Bischoff, R. Garcia-Campelo, N. Iannotti, P. Reiterer, I. Bover, J. Prendiville, A. J. Eisenfeld, F. B. Oldham, B. Bandstra, J. W. Singer and P. Bonomi, Br. J. Cancer, 2008, 98, 16081613.

C. J. Langer, K. J. O’Byrne, M. A. Socinski, S. M. Mikhailov, K. Leśniewski-Kmak, M. Smakal, T. E. Ciuleanu, S. V. Orlov, M. Dediu, D. Heigener, A. J. Eisenfeld, L. Sandalic, F. B. Oldham, J. W. Singer and H. J. Ross, J. Thorac. Oncol., 2008, 3, $623-630$.

O. Altintas, A. P. Vogt, C. Barner-Kowollik and U. Tunca, Polymer Chemistry, 2012, 3, 34-34.

E. Blasco, B. V. K. J. Schmidt, C. Barner-Kowollik, M. Piñol and L. Oriol, Macromolecules, 2014, 47, 3693-3700.

S. Pispas, N. Hadjichristidis, I. Potemkin and A. Khokhlov, Macromolecules, 2000, 33, 1741-1746.

J. Yun, R. Faust, L. S. Szilágyi, S. Kéki and M. Zsuga, Macromolecules, 2003, 36, 1717-1723.

G. M. Soliman, A. Sharma, D. Maysinger and A. Kakkar, Chem. Commun. (Camb.), 2011, 47, 9572-9587.

G. M. Soliman, R. Sharma, A. O. Choi, S. K. Varshney, F. M. Winnik, A. K. Kakkar and D. Maysinger, Biomaterials, $2010,31,8382-8392$.

F. Nederberg, E. Appel, J. P. Tan, S. H. Kim, K. Fukushima, J. Sly, R. D. Miller, R. M. Waymouth, Y. Y. Yang and J. L. Hedrick, Biomacromolecules, $2009,10,1460-1468$ 
H. Yin, S.-W. Kang and Y. H. Bae, Macromolecules, 2009, 42, 7456-7464.

P. Perdih, S. Čebašek, A. Možir and E. Žagar, Molecules, 2014, 19, 19751,19768.

R. Kaplánek, M. Havlík, V. Král, P. Martásek and T. Bř́za, Synth. Commun., 2009, 40, 247-256.

A. Dondoni, Angew. Chem. Int. Ed. Engl., 2008, 47, 8995-8997.

G. J. M. Habraken, A. Heise and P. D. Thornton, Macromol. Rapid Commun., 2012, 33, 272-286.

G. J. M. Habraken, M. Peeters, C. H. J. T. Dietz, C. E. Koning and A. Heise, Polymer Chemistry, 2010, 1, 514.

R. E. Canfield, J. Biol. Chem., 1963, 238, 2698-2707.

L. R. Wetter and H. F. Deutsch, J. Biol. Chem., 1951, 192, 237-242.

T. Masuda, N. Ide and N. Kitabatake, Chem. Senses, 2005, 30, 667-681.

D. E. Kuehner, J. Engmann, F. Fergg, M. Wernick, H. W. Blanch and J. M. Prausnitz, The Journal of Physical Chemistry B, 1999, 103, $1368-1374$.

H. Kukula, H. Schlaad, M. Antonietti and S. Förster, J. Am. Chem. Soc., 2002, 124, 1658-1663.

C. Krejtschi and K. Hauser, Eur. Biophys. J., 2011, 40, 673-685.

E. A. Gooding, S. Sharma, S. A. Petty, E. A. Fouts, C. J. Palmer, B. E. Nolan and M. Volk, Chem. Phys., 2013, 422, 115-123.

R. A. Dragovic, C. Gardiner, A. S. Brooks, D. S. Tannetta, D. J. Ferguson, P. Hole, B. Carr, C. W. Redman, A. L. Harris, P. J. Dobson, P. Harrison and I. L. Sargent, Nanomedicine, 2011, 7, 780-788.

1. T. Kurinomaru, S. Tomita, S. Kudo, S. Ganguli, Y. Nagasaki and K. Shiraki, Langmuir, 2012, 28, 4334-4338.

52. J. M. Park, B. B. Muhoberac, P. L. Dubin and J. Xia, Macromolecules, 1992, 25, 290-295.

53. K. P. Wilson, B. A. Malcolm and B. W. Matthews, J. Biol. Chem., 1992, 267, 10842-10849.

54. M. R. Eftink, Biophys. J., 1994, 66, 482-501.

55. Z. Chi and S. A. Asher, The Journal of Physical Chemistry B, 1998, 102, 9595-9602.

56. T. Imoto, L. S. Forster, J. A. Rupley and F. Tanaka, Proc. Natl. Acad. Sci. U. S. A., 1972, 69, 1151-1155.

57.

58.

59.

60.

A. R. Rees and M. J. E. Sternberg, From Cells to Atoms: An Illustrated Introduction to Molecular Biology, Blackwell Scientific Publications, 1984.

A. Harada and K. Kataoka, J. Am. Chem. Soc., 1999, 121, 9241-9242.

B. Masschalck, R. V. Houdt, E. G. R. V. Haver and C. W. Michiels, Appl. Environ. Microbiol., 2001, 67, 339-344.

S. Tomita, L. Ito, H. Yamaguchi, G.-i. Konishi, Y. Nagasaki and K. Shiraki, Soft Matter, 2010, 6, 5320-5320.

61. M. Gregoritza, A. M. Goepferich and F. P. Brandl, J. Controlled Release, 2016, 238, 92-102. 